Volume 1 Issue 1 (2017) Pages 42 - 51

Jurnal Obsesi : Jurnal Pendidikan Anak Usia Dini

DOI: $10.31004 /$ obsesi.v1i1.30

\title{
Upaya Peningkatan Kemampuan Bahasa Anak Usia 4-5 Tahun melalui Kegiatan Menceritakan Kembali Isi Cerita di Kelompok Bermain Aisyiyah Gobah Kecamatan Tambang
}

\author{
Moh Fauziddin ${ }^{凶}$ \\ Prodi PG-PAUD FIP Universitas Pahlawan Tuanku Tambusai
}

\begin{abstract}
Abstrak
Penelitian bertujuan mengetahui peningkatan kemampuan bahasa anak melalui kegiatan kegiatan menceritakan kembali isi cerita pada anak usia 4-5 tahun di Kelompok Bermain (KB) Aisyiyah Gobah kecamatan Tambang. Permasalahan yang dihadapi adalah masih rendahnya kemampuan bahasa anak usia dini. Metode penelitian ini adalah penelitian tindakan kelas. Instrumen penelitian ini terdiri dari lembar observasi peningkatan kemampuan bahasa anak. Subjek penelitian adalah anak usia 4-5 tahun berjumlah 18 orang. Hasil penelitian didapatkan, sebelum dilakukan tindakan, kemampuan bahasa anak dalam kegiatan menceritakan kembali isi cerita anak yaitu anak yang BB (44\%) yang MB (38\%) BSH (18\%) dan yang BSB hanya (5,5\%). Setelah siklus I pertemuan 1 anak yang BB (25\%) yang MB $(30 \%)$ BSH (16\%) dan yang BSB hanya (8\%). siklus I pertemuan 2 anak yang BB (22\%) yang MB (44\%) BSH (22\%) dan yang BSB hanya (11\%). Siklus II pertemuan 1 siklus II anak yang BB (11\%) yang MB (36\%) BSH (38\%) dan yang B hanya (13\%). Siklus II Pertemuan ke 2 anak yang BB (8\%) yang MB (16\%) BSH (55\%) dan yang BSB (16\%). Dengan demikian dapat disimpulkan bahwa kemampuan bahasa anak dapat ditingkatkan melalui kegiatan menceritakan kembali isi cerita anak usia 4-5 tahun di kelompok bermain Aisyiyah Gobah kecamatan Tambang.
\end{abstract}

Kata Kunci : Kemampuan Bahasa, Kegiatan Menceritakan Kembali, Cerita

\begin{abstract}
The aim of this research is to know the improvement of children's language ability through the activity of retelling the story content in children aged 4-5 years in Aisyiyah Gobah Tambang Bermain (KB). The problem faced was still low ability of early childhood language. The method of this research was classroom action research. The instrument of this research consists of observation sheet of improvement of language ability of children. Research subjects are children aged 4-5 years amounted to 18 people. The result of the research was found, before the action, the ability of the children's language in the activity of retelling the children's story content was the BB (44\%) of the MB (38\%) BSH (18\%) and the BSB only (5.5\%). After the first cycle of 1 child meeting the BB $(25 \%)$ the MB $(30 \%)$ BSH (16\%) and the BSB only (8\%). Cycle I meeting 2 children who were BB (22\%) who MB (44\%) BSH (22\%) and the BSB only (11\%). Cycle II meetings 1 cycle II children who are BB (11\%) are MB (36\%) BSH (38\%) and B only (13\%). Cycle II The 2nd meeting of the children who were BB (8\%) were MB (16\%) BSH (55\%) and the BSB (16\%). Thus it can be concluded that the child's language skills can be improved through the activities of retelling the contents of the story of children aged 4-5 years in Aisyiyah Gobah group sub-district Tambang.
\end{abstract}

Keyword : Language Ability, Story, Retelling Activities

@ Jurnal Obsesi Prodi PG-PAUD FIP UPTT 2017

$\triangle$ Corresponding author :

Address : Jalan Sungai Kampar 32 Bangkinang Kab. Kampar ISSN 2356-1327 (Media Cetak)

Email : mfauziddin@gmail.com

ISSN 2549-8959 (Media Online) 


\section{PENDAHULUAN}

Pendidikan anak usia dini bertujuan untuk membantu meletakkan dasar ke arah perkembangan sikap, pengetahuan, keterampilan dan daya cipta yang diperlukan oleh anak didik dalam penyesuaian diri dengan lingkungannya dan untuk pertumbuhan dan perkembangan selanjutnya. (Republik Indonesia, 2003)

Masih menurut UU No 20 tahun 2003 tentang System pendidikan Nasional pasal 28. Pendidikan Anak Usia Dini (PAUD) diselenggarakan sebelum jenjang pendidikan dasar, PAUD pada jalur formal berbentuk Kelompok Bermain (TK), Raudhatul Athfal (RA), pada jalur non formal berbentuk kelompok bermain (KB). Taman Penitip Anak (TPA), pada jalur informal berbentuk pendidkan keluarga atau pendidikan yang diselenggarakan oleh lingkungan keluarga.(Republik Indonesia, 2003)

Dalam proses belajar mengajar pendidik sebaiknya menggunakan metode yang bervariasi agar proses pengajaran tidak membosankan, Bercerita merupakan suatu cara mengajar untuk menanamkan kebiasaan-kebiasaan yang baik.

Berdasarkan hasil observasi yang peneliti lakukan diketahui bahwa kemampuan bahasa anak masih rendah, hal ini dapat dilihat dari kegiatan menceritakan kembali isi cerita, yaitu 8 orang $(44 \%)$ Belum Berkembang, anak yang dinyatakan Mulai Berkembang 7 orang (38\%), sedangkan yang dinyatakan Berkembang Sesuai Harapan 2 orang anak (11\%) dan yang Berkembang Sangat Baik 1 orang $(5,5 \%)$.

Berdasarkan observasi awal yang peneliti lakukan rendahnya kemampuan bahasa disebabkan karena dalam proses pembelajaran anak kurang percaya diri dan anak tidak bisa melakukan kegiatan yang menarik dalam belajar yang bisa menumbuh kembangkan kepercayaan dirinya sendiri, anak cendrung pasif dan kurang kreatif dalam proses pembelajaran.

Usaha yang telah dilakukan guru untuk meningkatkan kemampuan bahasa anak adalah dengan menggunakan berbagai cara diantaranya adalah dengan menerapkan bercerita secara bersama di dalam kelas.

Pokok permasalahan yang ditemukan di Kelompok Bermain Aisyiyah Gobah Kecamatan Tambang adalah sebagian anak terlihat kurang punya kemampuan berbahasa, anak kurang percaya diri dan tidak bisa melakukan kegiatan bercerita yang diminta guru, kurang menumbuh kembangkan kemampuan dirinya untuk berbahasa, dan cenderung pasif, kurang kreatif dalam proses membaca

Berdasarkan permasalahan di atas maka peneliti mengajukan alternatif pemecahan masalah dengan mencoba menerapkan megiatan menceritakan Kembali isi merita di Kelompok Bermain Aisyiyah Gobah Kecamatan Tambang.

Penelitian ini bertujuan: mengetahui penerapan dan peningkatan kemampuan bahasa anak melalui kegiatan menceritakan kembali isi cerita pada anak usia 4-5 tahun di kelompok bermain Aisyiyah Gobah kecamatan Tambang

Kemampuan adalah kesanggupan, kekuatan untuk melakukan sesuatu kemampuan juga merupakan suatu hal yang ingin dicapai seseorang dalam melakukan sesuatu. (Pusat Bahasa, 2008).

Kemampuan menceritakan kembali isi cerita pokok terdiri atas empat kemampuan yang harus dimiliki satu dari di antaranya adalah membaca. Membaca merupakan salah satu bagian atau komponen dari komunikasi tulisan. Membaca pada hakikatnya adalah suatu yang rumit yang melibatkan banyak hal, tidak hanya melafalkan tulisan, tetapi juga melibatkan aktivitas visual, berfikir, psikolingustik dan metakognitif.

Membaca pada anak usia dini lebih ditekankan pada persiapan membaca atau tahap awal anak untuk dapat membaca pada pendidikan selanjutnya yang lebih ditekankan pada pengenalan simbol-simbol huruf yang dikenal sampai memahami arti kata dalam cerita. (Risna et al., 2016)

Kegiatan Menceritakan Kembali isi Cerita adalah cara yang di dalam fungsinya merupakan alat untuk mencapai suatu tujuan. Selanjutnya metode mengajar 
seperti yang dikemukakan (Sudjana, 2013) bahwa metode mengajar adalah cara yang digunakan guru dalam mengadakan hubungan dengan siswa pada saat berlangsungnya pengajaran. Oleh karena itu peranan metode mengajar sebagai alat untuk menciptakan proses mengajar dan belajar.

Kegiatan menceritakan kembali isi cerita adalah metode penyampaian atau penyajian meteri pembelajaran secara lisan dalam bentuk bercerita dari guru keepada anak didik Kelompok Bermain. Kegiatan menceritakan kembali isi cerita dilaksanakan dalam upaya memperkenalkan, memberikan keterangan atau penjelasan tentang hal baru dalam rangka penyampaian pembelajaran yang dapat mengembangkan berbagai kopentensi dasar anak di Kelompok Bermain

Kegiatan bercerita dilaksanakan pada kegiatan penutup, sehingga ketika anak pulang anak menjadi tenang dan senang. Kegiatan bercerita pada prakteknya tidak selalu pada saat kegiatan penutup, dapat dilakukan pada saat kegiatan pembukaan, kegiatan inti, atau waktu-waktu senggang di sekolah. Misalnya pada saat waktu istirahat, karena mendengarkan cerita adalah suatu yang memberi manfaat bagi anak Kelompok Bermain.

Kemampuan berbicara sangat penting untuk anak karena dengan berbicara anak dapat mengkomunikasikan tentang keadaan dirinya.Misalnya, kasus anak yang kehilangan orangtuanya di pusat perbelanjaan. Hal ini dikarenakan anak sulit untuk berkomunikasi dengan oranglain, menyampaikan maksud dan menjelaskan keadaan dirinya dengan oranglain. Kasus hilangnya anak di pusat perbelanjaan ini merupakan salah satu bukti bahwa kemampuan berbicara adalah hal yang penting. (Pangestuti, 2016)

Bercerita bagi seorang anak adalah sesuatu yang menyenangkan melalui cerita anak dapat mengembangkan imajinasinya menjadi apapun yang diinginkan. Dalam cerita seorang anak dapat memperoleh nilai yang banyak dan berarti bagi proses pembelajaran dan perkembangannya termasuk kemampuan menceritakan kembali isi cerita dan sosialnya.

Tujuan bercerita bagi anak usia 4-5 tahun adalah agar anak mampu mendengarkan dengan seksama terhadap apa yang disampaikan oleh orang lain, anak dapat bertanya apabila tidak memahaminya, anak dapat menjawab pertanyaan, selanjutnya anak dapat menceritakan dan mengekspresikan terhadap apa yang didengarkan dan diceritakannya sehingga hikma dari isi cerita dapat dipahami dan lambat laun didengarkan, diperhatikan, dilaksanakan dan diceritakan kepada orang lain.

Bercerita kepada anak memainkan peranan penting bukan saja dalam menumbuhkan minat kebiasaan membaca, tetapi juga dalam mengembangkan bahasa dan pikiran anak. "Fungsi kegiatan bercerita bagi anak usia 4-5 tahun adalah membentuk perkembangan bahasa anak, dengan bercerita pendengaran anak dapat dipungsikan dengan baik untuk membantu kemampuan bicara, dengan menambah pembendaharan kosa kata, kemampuan mengucapkan kata-kata, berlatih merangkaikan kalimat sesuai dengan tahap perkembangan, anak juga dapat mengkreasikan dengan melalui bercerita, bersyair, menulis atau menggambar sehingga pada akhir anak dapat membaca setuasi, gambar, tulisan atau bahasa isarat. Kemampuan tersebut adalah hasil dari proses menyimak dalam tahap perkembangan bahasa anak.

Langkah bercerita dapat diuraikan sebagai berikut.

1. Anak memperhatikan guru menyiapkan alat peraga yang diperlukan

2. Anak memperhatikan penjelasan guru secara ringkas tentang alat tersebut

3. Anak memotivasi untuk mendengarkan cerita

4. Anak diberi kesempatan untuk memberi judul cerita

5. Anak mendengarkan judul cerita dari ibu guru

6. Anak mendengarkan guru bercerita sambil memegang alat tersebut 
7. Setelah selesai bercerita guru memberikan kesempatan kepada anak untuk memberikan kesimpulan cerita tersebut

8. Guru melengkapi kesimpulan isi cerita dari anak

9. Guru melaksanakan kegiatan evaluasi dengan bertanya tentang isi cerita, tokoh cerita, isi gambar dan memberi kesempatan kepada anak untuk menceritakan kembali. Guru pun memberi kesempatan kepada anak untuk bertanya. (Hidayat, 2003)

\section{HASIL DAN PEMBAHASAN Hasil Penelitian}

Sebelum dilakukan tindakan penelitian dengan penggunaan kegiatan menceritakan kembali isi cerita, dalam pelaksanaan pembelajaran anak terkesan menoton, kaku, kurang kreatif. Kondisi proses pembelajaran tersebut mengakibatkan kurang mampunya anak beraktivitas seperti yang diharapkan, kemampuan anak rendah, dalam proses pembelajaran

Berdasarkan hasil pengamatan dan pencatatan yang dilakukan terhadap kemampuan menceritakan kembali isi cerita anak sebelum dilakukan tindakan bahwa sebagian besar anak kemampuan menceritakan kembali isi cerita Belum Berkembang. Hasil observasi yang dilakukan pada setiap indikator kemampuan anak dalam menceritakan kembali isi cerita dapat dijelaskan sabagai berikut:

Menceritakan kembali isi cerita secara sederhana 8 orang $(44 \%)$ Belum Berkembang, sementara itu anak yang dinyatakan Mulai Berkembang hanya dengan prekwensi 7 orang (38\%), sedangkan yang dinyatakan Berkembang Sesuai Harapan dengan prekwensi 2 orang anak $(11 \%)$ dan yang Berkembang Sangat Baik hanya 1 orang $(5,5 \%)$.

Berdasarkan hasil refleksi awal yang penulis lakukan dijadikan dasar perbaikan pembelajaran kemampuan menceritakan kembali isi cerita anak melalui kegiatan menceritakan kembali isi cerita.

\section{Penjelasan Per-siklus Siklus Pertama}

Berdasarkan identifikasi masalah yang telah dikemukakan maka dapat disusun rancangan penelitian tindakan siklus pertama ini sebagai berikut: Sebelum melakukan tindakan pada siklus pertama terlebih dahulu guru menyusun perencanaan, adapun hal-hal yang akan dilakukan dalam penyususnan perencanaan siklus ke dua yaitu : menyiapkan Rencana Kegiatan Harian (RKH), dan menyiapkan lembar observasi.

Pertemuan pertama, pada 11 Desember 2016 tindakan pertama siklus ke I dilaksanakan dengan kegiatan anak berdoa sebelum dan sesudah melakukan kegiatan dengan lebih tertib. Selanjutnya seperti biasanya anak diajak untuk berdoa bersama dan dilanjutkan dengan mengucapkan salam, setelah itu anak diminta untuk bercerita tentang Indonesia yang berhubungan dengan beberapa pulau di Indonesia, lambang negara dan menceritakan kemabli secara urut

Kegiatan inti dilakukan guru dengan pemberian tugas mewarnai gambar bintang setelah guru membagikan krayon kepada setiap anak dan selanjutnya anak diberikan tugas untuk membuat angka 18. Tugas selanjutnya yang diberikan guru adalah bermain balok membuat istana setelah balok dibagikan anak diminta untuk melakukan kegiatan. Dan pemberian tugas mencocokkan gambar kepala banteng dalam hal ini guru meminta anak untuk merapikan pekerjaannya.

Anak diberi kesempatan untuk memberi judul cerita, mendengarkan judul cerita dari ibu guru tentang beberapa pulau di Indonesia dan menceritakan kemabali secara urut dan mendengarkan guru bercerita

Setelah selesai bercerita guru memberikan kesempatan kepada anak untuk memberikan kesimpulan cerita tersebut, melengkapi kesimpulan isi cerita dari anak. Guru melaksanakan kegiatan evaluasi dengan bertanya tentang isi cerita, tokoh cerita, isi gambar dan memberi kesempatan kepada anak untuk 
menceritakan kembali. Guru pun memberi kesempatan kepada anak untuk bertanya.

Pertemuan kedua pada 14 Desember 2016, pelaksanaan tindakan kedua siklus ke I dilaksanakan dengan kegiatan anak yang lebih banyak melakukan sesuatu ditambah dengan kegiatan anak yang lebih banyak melakukan sesuatu ditambah dengan kegiatan anak yang lebih banyak bercerita.

Pada kegiatan inti dengan seperti hari sebelumnya guru membagikan krayon warna kepada anak-anak. Karena telah terbiasa anak tampak bersemangat ketika menerima krayon yang dibagikan guru, selanjutnya guru meminta anak untuk mewarnai dan gambar bintang dan mencocok gambar kepala binatang. Kegiatan akhir adalah penutup dengan kegiatan yaitu menceritakan setiap kata yaitu "bercerita berbuat baik sesama teman" selanjutnya anak dibimbing berdoa bersama dan sebagai akhir proses pembelajaran adalah berdoa salam penutup

Berdasarkan tindakan yang telah dilaksanakan pada siklus pertama dengan dua kali pertemuan yaitu pertemuan pertama dan pertemuan ke dua, diketahui hasil dari observasi yang dilakukan terhadap aktivitas guru dalam proses pembelajaran telah berjalan sesuai dengan skenario yang susun sebelumnya. Namun dalam pelaksanaanya masih terdapat beberapa kelemahan, untuk lebih jelasnya dapat dilihat pada tabel berikut.

\begin{tabular}{|l|l|l|l|l|l|}
\hline No & $\begin{array}{l}\text { Aktivitas Guru Yang } \\
\text { Diamati SS }\end{array}$ & S & CS & KS \\
\hline 1 & $\begin{array}{l}\text { Guru meminta anak } \\
\text { Menceritakan can } \\
\text { kembali isi cerita } \\
\text { secara sederhana }\end{array}$ & & & $\sqrt{ }$ & \\
\hline 2 & $\begin{array}{l}\text { Guru meminta anak } \\
\text { Menceritakan } \\
\text { kembali isi cerita } \\
\text { sesuai dengan bahasa } \\
\text { anak itu sendiri }\end{array}$ & & & & $\sqrt{ }$ \\
\hline 3 & $\begin{array}{l}\text { Guru meminta anak } \\
\text { Anak dapat } \\
\text { menceritakan an cerita } \\
\text { kembali isi } \\
\text { dengan utuh dengan } \\
\text { bahasa buku }\end{array}$ & & $\sqrt{ }$ & \\
\hline
\end{tabular}

\begin{tabular}{|l|l|l|l|l|l|}
\hline No & $\begin{array}{l}\text { Aktivitas Guru Yang } \\
\text { Diamati }\end{array}$ & SS & S & CS & KS \\
\hline 4 & $\begin{array}{l}\text { Guru meminta anak } \\
\text { Anak dapat } \\
\text { menceritakan } \\
\text { kembali isi cerita } \\
\text { dengan utuh dengan } \\
\text { bahasa anak }\end{array}$ & & & $\sqrt{ }$ & \\
\hline
\end{tabular}

Keterangan:

$\mathrm{SS}=$ Sangat sempurna

$\mathrm{S}=$ Sempurna

$\mathrm{CS}=$ Cukup Sempurna

$\mathrm{KS}=$ Kurang sempurna

Berdasarkan pengamatan yang

dilakukan diketahui bahwa kemampuan bahasa anak melalui kegiatan pembelajaran dengan bercerita belum menunjukkan peningkatan yang signifikan. Aktivitas anak dalam proses pembelajaran dengan kegiatan menceritakan kembali isi cerita belum menunjukkan hasil yang maksimal. Banyak anak yang belum paham dengan cerita yang di sampaikan oleh guru, sehingga perhatian anak terhadap kegiatan tersebut dinilai kurang.

Aktivitas siswa dalam kegiatan menceritakan kembali isi cerita siklus 1

\begin{tabular}{|c|l|l|c|}
\hline \multirow{2}{*}{ No } & \multicolumn{1}{|c|}{ Aktivitas Siswa } & \multicolumn{2}{|c|}{ Pertemuan 1 } \\
\cline { 3 - 4 } 1 & $\begin{array}{l}\text { Anak memperhatikan } \\
\text { guru }\end{array}$ & 12 & $66 \%$ \\
\hline 2 & $\begin{array}{l}\text { Anak mendengarkan } \\
\text { cerita yang disampaikan } \\
\text { guru }\end{array}$ & 14 & $77 \%$ \\
\hline 3 & $\begin{array}{l}\text { Anak mau berpartisipasi } \\
\text { dalam menceritakan } \\
\text { kembali isi cerita }\end{array}$ & 14 & $77 \%$ \\
\hline 4 & $\begin{array}{l}\text { Anak antusias } \\
\text { menceritakan kembali } \\
\text { isi cerita dengan bahasa } \\
\text { anak }\end{array}$ & 10 & $55 \%$ \\
\hline \multirow{2}{*}{ Jumlah } & 50 & $227 \%$ \\
\cline { 3 - 4 } & 12,5 & $68,75 \%$ \\
\hline
\end{tabular}

Dari data diatas diketahui tejadi peningkatan aktivitas siswa pada siklus 1 pertemuan 1 menjadi $68,75 \%$ dikategorikan sedang, hal ini dikarenakan, siswa mulai merasa nyaman dengan pembelajaran yang dilakukan, dan guru mulai percaya diri dalam mengajar.

\section{Hasil Belajar Siswa}

Berdasarkan hasil pengamatan terhadap kemampuan bahasa anak pada siklus pertama pertemuan 1 dan 2 dapat dilihat pada tabel di bawah ini. 
Tabel Data Kemampuan Bahasa dalam Menceritakan Isi Cerita Siklus I Pertemuan 1

\begin{tabular}{|l|l|c|c|c|c|c|c|c|}
\hline \multirow{2}{*}{ INDIKATOR } & \multicolumn{7}{|c|}{ KATEGORI } \\
\cline { 2 - 9 } & \multicolumn{2}{|c|}{ BB } & \multicolumn{2}{|c|}{ MB } & \multicolumn{2}{|c|}{ BSH } & \multicolumn{2}{c|}{ BSB } \\
\cline { 2 - 8 } & Frk & $\%$ & Frk & $\%$ & Frk & $\%$ & Frk & $\%$ \\
\hline $\begin{array}{l}\text { Menceritakan } \\
\text { kembali isi } \\
\text { cerita }\end{array}$ & 5 & 27 & 9 & 50 & 3 & 16 & 1 & 5,5 \\
\hline
\end{tabular}

Keterangan:

BB : Belum Berkembang

MB : Mulai Berkembang

BSH : Berkembang Sesuai Harapan

BSB : Berkembang Sangat Baik

Berdasarkan tabel di atas, dapat dilihat bahwa sebagian besar anak kemampuan menceritakan kembali isi cerita Belum Berkembang. Hasil observasi yang dilakukan pada setiap indikator kemampuan anak dalam menceritakan kembali isi cerita dapat dijelaskan sabagai berikut:

Menceritakan kembali isi cerita secara sederhana 5 orang $(27 \%)$ Belum Berkembang, sementara itu anak yang dinyatakan Mulai Berkembang hanya dengan prekwensi 9 orang (50\%), sedangkan yang dinyatakan Berkembang Sesuai Harapan dengan prekwensi 3 orang anak $(16 \%)$ dan yang Berkembang Sangat Baik hanya 1 orang $(5,5 \%)$.

Sedangkan hasil observasi yang dilakukan pada pertemuan ke 2 siklus pertama terhadap tingkat kemampuan menceritakan kembali isi cerita anak dapat dilihat pada tabel di bawah ini.

Data Kemampuan Bahasa Anak dalam Menceritakan Isi Cerita Siklus I Pertemuan 2

\begin{tabular}{|l|l|l|l|l|l|l|l|c|}
\hline \multirow{2}{*}{ INDIKATOR } & \multicolumn{9}{|c|}{ KATEGORI } \\
\cline { 2 - 9 } & \multicolumn{2}{|c|}{ BB } & \multicolumn{2}{c|}{ MB } & \multicolumn{2}{c|}{ BSH } & \multicolumn{2}{c|}{ BSB } \\
\cline { 2 - 9 } & Frk & $\%$ & Frk & $\%$ & Frk & $\%$ & Frk & $\%$ \\
\hline $\begin{array}{l}\text { Menceritakan } \\
\text { kembali isi } \\
\text { cerita }\end{array}$ & 4 & 22 & 8 & 44 & 4 & 22 & 2 & 11 \\
\hline
\end{tabular}

Keterangan:

BB : Belum Berkembang

MB : Mulai Berkembang

BSH : Berkembang Sesuai Harapan

BSB : Berkembang Sangat Baik

Berdasarkan tabel di atas, dapat dilihat bahwa sebagian besar anak kemampuan menceritakan kembali isi cerita Belum Berkembang. Hasil observasi yang dilakukan pada setiap indikator kemampuan anak dalam menceritakan kembali isi cerita dapat dijelaskan sabagai berikut:
Menceritakan kembali isi cerita secara sederhana 4 orang (22\%) Belum Berkembang, sementara itu anak yang dinyatakan Mulai Berkembang hanya dengan prekwensi 8 orang (44\%), sedangkan yang dinyatakan Berkembang Sesuai Harapan dengan prekwensi 4 orang anak $(22 \%)$ dan yang Berkembang Sangat Baik hanya 2 orang (11\%).

Aktivitas yang dilakukan guru selama proses pada umumnya telah terlaksana dengan cukup sempurna. Kemampuan bahasa anak setelah dilakukan pengamatan ternyata telah lebih baik dari sebelum dilakukan tindakan. Aktivitas yang dilakukan guru terutama dalam meminta anak Menceritakan kembali isi cerita sesuai dengan bahasa anak itu sendiri masih dilakukan guru dengan kurang sempurna

Kemampuan bahasa anak walaupun sudah meningkat namun masih banyak ditemui anak yang belum mampu Menceritakan kembali isi cerita secara sederhana

Rencana perbaikan yang dilakukan guru pada siklus berikutnya adalah guru akan berusaha melakukan bimbingan anak untuk mewarnai dengan lebih baik dari siklus pertama dan guru akan berusaha melakukan bimbingan anak mengulas kegiatan dengan membaca setiap kata lebih sempurna lagi.

Dalam upaya peningkatan kemampuan bahasa anak guru akan berusaha untuk lebih meningkatkan dengan memberikan bimbingan yang lebih baik terutama dalam memperhatikan penjelasan guru secara ringkas, mendengarkan judul cerita dari ibu guru, melengkapi kesimpulan isi cerita dalam belajar.

\section{Siklus Kedua}

Berdasarkan hasil refleksi yang dilakukan pada siklus pertama yang telah dikemukakan maka dapat disusun rancanagan dalam penelitian tindakan siklus kedua ini.

Sebelum melakukan tindakan pada siklus kedua terlebih dahulu guru menyusun perencanaan. Siklus kedua dilaksanakan pada 15 Desember 2016. 
Pelaksanaan siklus ke kedua pertemuan pertama dilaksanakan dengan kegiatan anak yang lebih banyak melakukan sesuatu ditambah dengan kegiatan anak yang lebih banyak mendengarkan dan menceritakan kemabali secara urut tentang "pohon beringin"

Langkah-langkah perbaikan pembelajaran dimulai dengan kegiatan pendahuluan dengan kegiatan yaitu dengan mengajak anak berdoa dan mengucapkan salam dilanjutkan dengan mernyanyi bersama. Kemudian guru bersama anak bercerita tentang "beberapa pulau di Indonesia"

Pada kegiatan inti guru mengajak anak-anak "Menggunting pohon beringin" dan guru membagikan gunting dan pola pohon beringin kepada anak-anak. Guru meminta anak menggunting gambar dengan hati-hati. Anak-anakpun merasa sangat bersemangat menerima tugas dari ibu guru. Selanjutnya guru membimbing anak untuk bekerja dengan hati-hati hingga mebentuk "pohon beringin" Pada kegiatan penutup kegiatan yang dilakukan adalah bercerita orang yang lebih tua

Pertemuan ketiga 16 Desember 2016 dilaksanakan dengan langkah pembelajaran yaitu anak yang lebih banyak melakukan sesuatu ditambah dengan kegiatan anak yang lebih banyak berpikir. Dalam RKH ini anak-anak akan bercerita tentang gambar yang disediakan atau yang dibuat dengan urut dan bahasa yang jelas tentang "pohon beringin"

Sebelum pelaksanaaan tindakan pada terlebih dahulu dilakukan penataan ruang diubah untuk membentuk lingkaran kemudian pengorganisasian anak posisi anak diubah menjadi bentuk lingkaran yang dirancang oleh guru. Langkahlangkah perbaikan kegiatan anak yang lebih banyak melakukan sesuatu ditambah dengan kegiatan anak yang lebih banyak berpikir Dalam RKH ini anak-anak akan bercerita tentang gambar yang disediakan atau yang dibuat dengan urut dan bahasa yang jelas tentang "beberapa pulau di Indonesia"

$$
\text { Langkah-langkah perbaikan }
$$
dimulai dengan menjelaskan bagaimana cara menyampaikan pesan berantai kepada anak secara berbisik. Kemudian guru meminta anak satu persatu secara bergantian menyampaikan pesan berantai. Anak satu persatu secara bergantian menyampaikannya dengan cara berbisik, demikian seterusnya hingga semua anak dapat giliran

Pegelolaan kelompok belajar penataan kelompok belajar yang semula posisi duduk berbanjar diubah menjadi penataan kelompok belajar yang dapat digunakan untuk membentuk bujur sangkar. Anak-anak diajak membentuk bujur sangkar dan mengikuti pesan berantai secara bergantian.

Pada kegiatan penutup kegiatan yang dilakukan adalah dengan mengulas kegiatan dengan menceritakan setiap kata yang dari pesan berantai yang telah dilakukan yaitu tentang "Menggunting pohon beringin" selanjutnya anak dibimbing untuk berdoa bersama dan salam penutup.

Berdasarkan pengamatan aktivitas guru dan tingkat Menceritakan Kembali isi Cerita belajar anak yang telah dilakukan ternyata aktivitas yag dilakukan guru telah sesuai dengan skenario yang disusun sebelumnya.

Pada pertemuan ke 3 siklus ke II di atas dapat dijelaskan aktivitas yang dilakukan guru pada setiap indikator yaitu: Guru meminta anak Menceritakan kembali isi cerita secara sederhana Sempurna, Guru meminta anak Menceritakan kembali isi cerita sesuai dengan bahasa anak itu sendiri Sempurna, Guru meminta anak Anak dapat menceritakan kembali isi cerita dengan utuh dengan bahasa buku Cukup Sempurna, Guru meminta anak Anak dapat menceritakan kembali isi cerita dengan utuh dengan bahasa anak Cukup Sempurna.

Setelah Proses pembelajaran pada pertemuan ketiga siklus ke II maka dilakukan pengamatan pada pertemuan keempat siklus II hasil pengamatan dapat dijelaskan aktivitas yang dilakukan guru pada setiap indikator yaitu: Guru meminta anak Menceritakan kembali isi cerita secara sederhana Sempurna, Guru meminta 
anak Menceritakan kembali isi cerita sesuai dengan bahasa anak itu sendiri Sempurna, Guru meminta anak Anak dapat menceritakan kembali isi cerita dengan utuh dengan bahasa buku Sempurna, Guru meminta anak Anak dapat menceritakan kembali isi cerita dengan utuh dengan bahasa anak Sempurna.

Sedangkan pada aktivitas siswa terjadi peningkatan yang signifikan pada aktivitas siswa pada siklus 2 pertemuan 1 mencapai $84,25 \%$ dengan kategori sangat tinggi, hal ini sangat dimungkinkan karena siswa mulai merasa nyaman dan menyenangkan dalam pembelajaran, sementara guru semakin terampil.

Aktivitas siswa pada siklus 2 pertemuan 2 mencapai $92,5 \%$ dengan kategori sangat tinggi, hal ini sangat dimungkinkan karena siswa mulai merasa nyaman dan menyenangkan dalam pembelajaran, sementara guru semakin menguasai materi dan terampil dalam membawa siswa

Hasil observasi yang dilakukan pada setiap indikator kemampuan anak dalam menceritakan kembali isi cerita dapat dijelaskan sabagai berikut:

Menceritakan kembali isi cerita secara sederhana 2 orang (11\%) Belum Berkembang, sementara itu anak yang dinyatakan Mulai Berkembang hanya dengan prekwensi 5 orang (27\%), sedangkan yang dinyatakan Berkembang Sesuai Harapan dengan prekwensi 8 orang anak (44\%) dan yang Berkembang Sangat Baik hanya 3 orang (16\%).

Hasil observasi yang dilakukan pada setiap indikator kemampuan anak dalam menceritakan kembali isi cerita dapat dijelaskan bahwa kegiatan menceritakan kembali isi cerita secara sederhana 2 orang (11\%) Belum Berkembang, sementara itu anak yang dinyatakan Mulai Berkembang hanya dengan prekwensi 2 orang (11\%), sedangkan yang dinyatakan Berkembang Sesuai Harapan dengan prekwensi 10 orang anak (55\%) dan yang Berkembang Sangat Baik hanya 3 orang (16\%).

Memperhatikan deskripsi proses pembelajaran siklus ke II yang diuraikan di atas dan melihat tingkat kemampuan bahasa anak dalam menceritakan kembali isi cerita maka berdasarkan diskusi peneliti dengan observer terhadap perbaikan pembelajaran pada siklus ke II, terdapat beberapa catatan sebagai hasil refleksi diantaranya adalah : Aktivitas yang dilakukan guru selama proses pembelajaran berlangsung telah sesuai dengan skenario pembelajaran yang disusun sebelumnya, pelaksanaannya terdapat beberapa kakuatan yang dapat dijadikan sebagai catatan sebagai hasil refleksi yaitu aktivitas selama proses pembelajaran telah terlaksana dengan sempurna, Kemampuan menceritakan kembali isi cerita anak dalam belajar setelah dilakukan pengamatan ternyata telah seperti harapan karena dalam perkembangannya menunjukkan peningkatan

Berdasarkan hasil refleksi yang dilakukan pada siklus ke II ternyata pelaksanaan proses pembelajaran dan tingkat kemampuan bahasa anak melalui Menceritakan Kembali isi Cerita telah lebih baik dari hasil siklus pertama. Peneliti dan observer menyimpulkan bahwa penelitian tindakan yang dilakukan telah berhasil dan tidak dilanjutkan pada siklus berikutnya.

\section{PEMBAHASAN \\ Siklus Pertama}

Berdasarkan hail pengamatan yang telah dilakukan pada siklus I pertemuan pertama dalam pelaksanaannya secara umum masih dilakukan guru dengan cukup sempurna terutama dalam menceritakan kembali isi cerita secara sederhana, menceritakan kembali isi cerita sesuai dengan bahasa anak itu sendiri, mmeminta anak Anak dapat menceritakan kembali isi cerita dengan utuh dengan bahasa buku dan menceritakan kembali isi cerita dengan utuh dengan bahasa. Begitupula pada pertemuan kedua aktivitas yang dilakukan guru masih pada kategori cukup sempurna

Aktivitas yang dilakukan guru selama proses pembelajaran berlangsung telah sesuai dengan skenario pembelajaran yang disusun sebelumnya. Aktivitas yang 
dilakukan guru selama proses pada umumnya telah terlaksana dengan cukup sempurna.

Diketahui bahwa aktivitas siswa pada siklus 1 pertemuan 1 sebesar 55,25\% dikategorikan sedang hal ini dimungkinkan karena siswa baru mengikuti kegiatan ini dan guru pun baru menerapkan pembelajaran tersebut. Dari data di atas diketahui tejadi peningkatan aktivitas siswa pada siklus 1 pertemuan 1 menjadi $68,75 \%$ dikategorikan sedang, hal ini dikarenakan, siswa mulai merasa nyaman dengan pembelajaran yang dilakukan, dan guru mulai percaya diri dalam mengajar

Berdasarkan hasil pengamatan dan pencatatan yang dilakukan terhadap kemampuan bahasa anak pada siklus I yang dilakukan dengan dua kali pertemuan yaitu pertemuan pertama dan pertemuan ke dua dan hal yang ditingkatkan yaitu Menceritakan kembali isi cerita secara sederhana, Menceritakan kembali isi cerita sesuai dengan bahasa anak itu sendiri, Anak dapat menceritakan kembali isi cerita dengan utuh dengan bahasa buku, Anak dapat menceritakan kembali isi cerita dengan utuh dengan bahasa anak.

Telah terjadi penurunan jumlah dan persentase kemampuan bahasa anak melalaui menceritakan kembali isi cerita Siklus I belum berkembang pertemuan pertama yaitu $25 \%$ pertemuan ke 2 yaitu $22 \%$. Mulai berkembang pertemuan pertama $50 \%$ dan pertemuan kedua $44 \%$ Berkembang sesuai Harapan Pertemuan pertama $16 \%$ dan pertemuan kedua $22 \%$. Berkembang sangat baik pertemuan pertama $8 \%$ dan pertemuan kedua $11 \%$.

\section{Siklus Kedua}

Berdasarkan hasil observasi guru pada pertemuan ke 3 siklus ke II di dijelaskan aktivitas yang dilakukan guru sudah terlaksana dengan sempurna terutama dalam meminta anak menceritakan kembali isi cerita secara sederhana, meminta anak menceritakan kembali isi cerita sesuai dengan bahasa anak itu sendiri, meminta anak menceritakan kembali isi cerita dengan utuh dengan bahasa buku. Secara umum aktivitas yang dilakukan guru pada siklus ke II lebih baik dari aktivitas yang dilakukan pada siklus pertama.

Aktivitas siswa pada siklus 2 pertemuan 2 mencapai $92,5 \%$ dengan kategori sangat tinggi, hal ini sangat dimungkinkan karena siswa mulai merasa nyaman dan menyenangkan dalam pembelajaran, sementara guru semakin menguasai materi dan terampil dalam membawa siswa

Aktivitas siswa pada siklus 2 pertemuan 1 mencapai $84,25 \%$ dengan kategori sangat tinggi, hal ini sangat dimungkinkan karena siswa mulai merasa nyaman dan menyenangkan dalam pembelajaran, sementara guru semakin terampil.

Kemampuan Bahasa anak dapat dilihat pada grafik berikut ini.

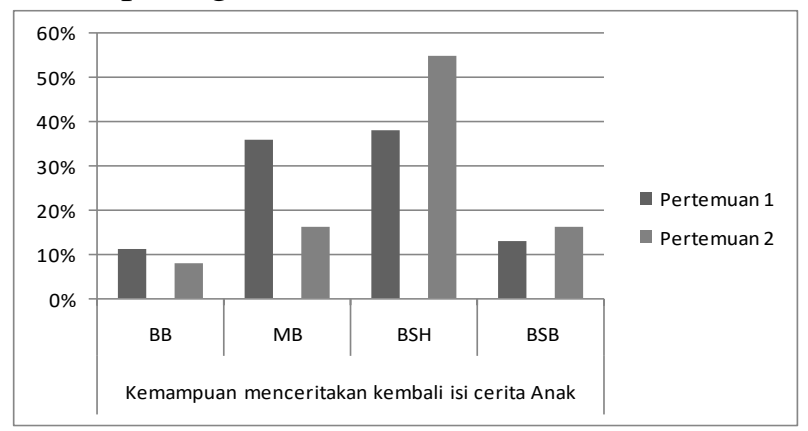

Berdasarkan grafik perkembangan kemampuan bahasa anak melalaui menceritakan kembali isi cerita dari pertemuan pertama siklus ke I sampai peremuan ke 4 siklus ke II dapat dilihat bahwa telah terjadi peburunan jumlah dan persentase perkembangan anak yang belum berkembang dan peningkatan jumlah dan persentase anak yang sudah berkembang sesuai harapan.

Memperhatikan deskripsi proses pembelajaran yang telah dilakukan pada siklus pertama terdapat beberapa catatan yang dapat dijadikan sebagai refleksi, pada siklus pertama proses pembelajaran yang dilaksanakan belum seperti harapan dalam penelitian ini. Berdasarkan pengamatan yang dilakukan terhadap aktivitas yang dilakukan guru dan tingkat kemampuan bahasa anak melalaui menceritakan kembali isi cerita dapat dijelaskan bahwa aktivitas yang dilakukan guru selama proses pembelajaran berlangsung telah sesuai dengan skenario pembelajaran yang 
disusun sebelumnya, namun dalam pelaksanaannya masih terdapat beberapa kelemahan yang dapat dijadikan sebagai catatan sebagai hasil refleksi yaitu dalam memperhatikan penjelasan guru secara ringkas, mendengarkan judul cerita dari ibu guru, melengkapi kesimpulan isi cerita dari anak terlaksana dengan kurang sempurna.

Kemampuan bahasa anak melalaui menceritakan kembali isi cerita setelah dilakukan pengamatan ternyata belum seperti harapan, namun telah menunjukkan peningkatan yaitu berdasarkan pengamatan kemampuan menceritakan kembali isi cerita aanak pada umumnya telah mulai muncul

Kondisi proses pembelajaran pada siklus pertama ternyata belum seperti harapan dalam penelitian ini maka penulis dan observer merencanakan tindakan berikutnya yaitu siklus ke II. Kelemahankelemahan yang terjadi pada siklus pertama menjadi fokus perbaikan pada siklus ke II.

Setelah dilakukan perbaikan pada siklus ke II, ternyata terjadi perubahan pada aktivitas yang dilakukan guru yang lebih sempurna pada pelaksanaan siklus pertama. Dengan samakin sempurnanya proses pembelajaran yang dilaksanakan guru mempengaruhi tingkat kemampuan bahasa anak melalaui menceritakan kembali isi cerita.

\section{KESIMPULAN}

Berdasarkan hasil penelitian di atas, maka dapat disimpulkan sebagai berikut melalui Kegiatan Menceritakan Kembali isi Cerita pada anak usia 4-5 tahun di kelompok bermain Aisyiyah Gobah kecamatan Tambang dapat meningkatkan bahasa anak di Kelompok Bermain Aisyiyah Gobah Kecamatan Tambang.

Hal itu dapat dilihat dari hasil penelitian yang dilakukan dua siklus yaitu sebelum dilakukan tindakan tingkat kemampuan bahasa anak dalam kegiatan menceritakan kembali isi cerita anak yaitu anak yang Belum Berkembang (44\%) yang Mulai Berkembang (38\%) Berkembang Sesuai Harapan (18\%) dan yang Berkembang Sangat Baik hanya $(5,5 \%)$. Setelah siklus I pertemuan 1 anak yang Belum Berkembang (25\%) yang
Mulai Berkembang (30\%) Berkembang Sesuai Harapan (16\%) dan yang Berkembang Sangat Baik hanya (8\%). siklus I pertemuan 2 anak yang Belum Berkembang (22\%) yang Mulai Berkembang (44\%) Berkembang Sesuai Harapan (22\%) dan yang Berkembang Sangat Baik hanya (11\%). Siklus II pertemuan 3 siklus anak yang Belum Berkembang (11\%) yang Mulai Berkembang (36\%) Berkembang Sesuai Harapan (38\%) dan yang Berkembang Sangat Baik hanya (13\%). Siklus II Pertemuan ke 4 anak yang Belum Berkembang (8\%) yang Mulai Berkembang (16\%) Berkembang Sesuai Harapan (55\%) dan yang Berkembang Sangat Baik hanya (16\%).

\section{UCAPAN TERIMA KASIH}

Terima kasih penulis ucapkan kepada Tim Editor E-Journal Obsesi yang sudah memberikan kesempatan sehingga jurnal ini siap untuk diterbitkan, tidak lupa pula saya ucapkan rangkaian terima kasih yang sebesar besarnya kepada reviewer yang sudah mau meluangkan waktunya untuk meriview serta memberikan banyak masukan sehingga jurnal ini lebih sempurna. Untuk semua teman sejawat dosen dosen Universitas Pahlawan Tuanku Tambusai yang telah memberikan semangat dalam penulisan ini sehingga penulis dapat menyelesaikan tepat pada waktunya.

\section{DAFTAR PUSTAKA}

Hidayat. (2003). Menjadi Guru Propesional. Bandung: Remaja Rosdakarya.

Pangestuti, L. (2016). Peran Media Cerita Dalam Mengembangkan Kemampuan Berbicara pada anak melalui Kegiatan Show and Tell. Jurnal PAUD UNY, 2(2), 702-707.

Pusat Bahasa. (2008). Kamus Besar Bahasa Indonesia. (D. Sugono, Ed.). Jakarta: Pusat Bahasa Departemen Pendidikan Nasional.

Republik Indonesia, P. Undang-Undang Republik Indonesia, Pub. L. No. Nomor 20 Tahun 2003, 1 (2003). Republik Indonesia.

Risna, I., Sutini, A., Program, J., Pgpaud, S., Pendidikan, F. I., \& Indonesia, U. P. (2016). Meningkatkan Kemampuan Membaca Anak Usia Dini melalui Model Kooperatif Make A-Match. Antologi UPI, 1-16.

Sudjana, N. (2013). Penlilaian Hasil Belajar Mengajar. Bandung: PT Remaja Rosda Karya. 